\title{
Analiza wpływu dokładności pozycjonowania urządzenia QUICKCHECKwebline na pomiar parametrów wiązki promieniowania.
}

\section{Analysis of the impact of the QUICHCHECKwebline alignment on the measurement of the radiation beam parameters.}

\section{Marta Paluszyńskaํ, Olga Bąk ${ }^{1}$, Magdalena Charmacińska ${ }^{1}$, Urszula Sobocka-Kurdyk², Patrycja Borowska ${ }^{1}$}

\author{
${ }^{1}$ Zakład Fizyki Medycznej, Wielkopolskie Centrum Onkologii, Poznań, Polska \\ ${ }^{2}$ Zakład Fizyki Medycznej, Wielkopolskie Centrum Onkologii, Poznań, Polska; Wydziat Nauk o Zdrowiu, Akademia Kaliska, Kalisz, Polska
}

\section{Streszczenie}

Zapewnienie jakości leczenia radioterapeutycznego zależy od fizycznych parametrów wiązki promieniowania jonizującego. QUICKCHECK ${ }^{\text {webline }}$ T42031 (QCh) jest urządzeniem pomiarowym wykorzystywanym do kontroli jakości oraz stabilności pracy akceleratora medycznego wykorzystywanego w radioterapii. Urządzenie to w sposób zautomatyzowany mierzy dawkę w osi centralnej (ang. Central Axis, CAX), stałość profili wiązki, jej symetrię, czy na przykład indeks jakości promieniowania (ang. Beam Quality Factor, BQF).

Celem tej pracy było zbadanie wpływu dokładności ułożenia aparatury pomiarowej względem osi centralnej wiązki promieniowania na jej parametry. Zgodnie z rozporządzeniem Ministra Zdrowia własności te kontrolowane są nie rzadziej niż co kwartał oraz po każdej awarii aparatu mającej wpływ na charakterystykę wiązek. Zastosowanie urządzenia QCh pozwala na bieżącą kontrolę tych parametrów i przy zachowaniu należytej staranności w pozycjonowaniu urządzenia przekroczenie zastosowanych progów tolerancji powinno stanowić przesłankę do kontroli kształtu profili wiązki zgodnie z metodologią przedstawioną w raporcie IAEA TRS-398. Producent rekomenduje pozycjonowanie urządzenia za pomocą centratorów laserowych, których zakresy tolerancji zgodności z krzyżem symulacji świetlnej pola promieniowania określa Rozporządzenie Ministra Zdrowia w sprawie warunków bezpiecznego stosowania promieniowania jonizującego dla wszystkich rodzajów ekspozycji medycznej. Ułożenie przyrządu zgodnie ze wskazaniem

Adres do korespondencji

Marta Paluszyńska

Zakład Fizyki Medycznej,

Wielkopolskie Centrum Onkologii, ul. Garbary 15, 61-866 Poznań, Polska

Telefon. +48 61????????

e-mail: marta.paluszynska@wco.pl 
centratorów laserowych, których położenie mieści się w górnym limicie tolerancji, może prowadzić do niepewności pomiarowych i nieprawidłowej interpretacji wyników. Należy zaznaczyć, że tylko pomiar wykonany w prawidłowy sposób umożliwi szybkie i wiarygodne wykrycie nieprawidłowości analizowanych parametrów wiązki terapeutycznej.

Przeprowadzono porównanie wyników codziennej kontroli parametrów wiązek promieniowania kontrolowanych za pomocą urządzenia QCh wypozycjonowanego zgodnie z krzyżem symulacji świetlnej (przyjętych za referencyjne) z wynikami uzyskanymi przy pomiarze według założonych w pracy niezgodności ułożenia urządzenia. Pomiary zostały wykonane na aparacie TrueBeam (TB) firmy Varian (Varian Medical System, Palo Alto, USA).

Zaobserwowano, że sposób pozycjonowania urządzenia pomiarowego nie ma istotnego wpływu na wyznaczoną wartość CAX - współczynnik korelacji dla wyników wyznaczonych dla dwóch metod ułożenia QCh jest bliski jedności. Jednocześnie odnotowano, że w przypadku symetrii wiązki promieniowania wzajemna zgodność wyników jest znacząco niższa. Współczynniki korelacji Pearsona dla symetrii GT wynoszą o,27 dla energii 6 MV i o,29 dla 15 MV, a dla symetrii LR odpowiednio: o,27 i o,37. W teście polegającym na ocenie wpływu przesunięć urządzenia pomiarowego o zadanych wartościach na wyznaczone wartości parametrów wiązki promieniowania zaobserwowano, że zmiana położenia przyrządu o 3mm w dowolnym kierunku prowadziła do zmiany wartości symetrii względem wartości referencyjnej (wyznaczonej dla urządzenia nieprzesuniętego) o 6\%, 13\% przy przesunięciu o 5mm i 32\% przy przesunięciu o $7 \mathrm{~mm}$.

Aby urządzenie mogło było wiarygodnym narzędziem przy codziennych testach kontroli jakości należy dołożyć wszelkich starań, by było ono dokładnie wypozycjonowane, a centratory laserowe odpowiednio wyregulowane. Dla zwiększenia precyzji pomiarów, należy po ułożeniu przyrządu przy pomocy systemu laserowego zweryfikować zgodność pozycjonowania względem pola świetlnego i dokonać ewentualnych korekcji.

\section{Abstract}

Quality assurance in radiotherapy treatment depends on the physical parameters of the radiation beam. QUICKCHECK ${ }^{\text {webline }}$ T42031 is a measuring device used for quality assurance and constancy checks of medical accelerators used in radiation therapy. The device measures the central axis dose (CAX), the flatness of the field, the symmetry or the radiation quality (BQF).

The aim of this study was to analyze the impact of the QuickCheck alignment in relation to the central axis of the radiation beam on measurement of the beam parameters. According to the Regulation of the Minister of Health, these properties are checked at least every quarter and after each failure of the linac affecting the characteristics of the beams. The use of the QCh allows for ongoing control of these parameters and, with due diligence in the positioning of the device, exceeding the applied tolerance thresholds should be a premise for controlling the shape of the beam profiles in accordance with the methodology presented in the IAEA TRS-398 report. The manufacturer recommends positioning the device using laser systems. The tolerance ranges for compliance of lasers with the light field are specified in the Regulation of the Minister of Health on the conditions for safe use of ionizing radiation for all types of medical exposure. Aligning the QCh with a laser system that is within the upper tolerance limit can lead to measurement uncertainty and misinterpretation of the results. It should be noted that only the correct measurement will enable quick and reliable detection of irregularities in the analyzed beam parameters.

The results of the daily control of the parameters of the radiation beams controlled by the QCh positioned in accordance with the light field (assumed as reference) were compared with the results obtained during the measurement according to the device arrangement inconsistencies assumed in the study. Measurements were made on the Varian TrueBeam medical accelerator (Varian Medical System, Palo Alto, USA).

It was observed that the method of positioning the measuring device does not have a significant impact on the determined CAX value - the correlation coefficient for the results determined for the two methods of arranging the QCh is close to one. At the same time, it was noted that in the case of symmetry of the radiation beam, the mutual agreement of the results is significantly lower. Pearson's correlation coefficients for GT symmetry are 0.27 for $6 \mathrm{MV}$ energy and 0.29 for $15 \mathrm{MV}$, and for LR symmetry 0.27 (6MV) and 0.37 $(15 \mathrm{MV})$. In the test consisting in assessing the impact of shifts of the measuring device with set values on the 
parameters of the radiation beam, it was observed that changing the position of the device by $3 \mathrm{~mm}$ in any direction led to a change in the symmetry value in relation to the reference value (determined for the device not shifted) by $6 \%, 13 \%$ at the shift by $5 \mathrm{~mm}$ and $32 \%$ when offset by $7 \mathrm{~mm}$.

To make sure that the device is a reliable quality control tool, every effort should be made to ensure that it is accurately positioned and the laser system properly adjusted. To increase the precision of measurements, after positioning with a laser system, verify the positioning compliance with the light field and make any eorreetions.

\section{Wstęp}

W trakcie realizacji leczenia radioterapeutycznego niezwykle ważna jest regularna kontrola jakości pracy akceleratora medycznego. Zapewnia ją m. in. codzienna weryfikacja stałości wydajności oraz regularna ocena parametrów fizycznych wiązki promieniowana [1,2].

Jakość wiązki fotonowej wytwarzanej przez akceleratory medyczne jest określana przez takie parametry jak chociażby jej symetria czy stałość profili wiązek promieniowania (ang. Flatness). Są one regularnie kontrolowanie i w razie potrzeby regulowane - nie rzadziej niż co kwartał oraz po każdej awarii aparatu mającej wpływ na charakterystykę wiązek. Pomiary przeprowadza się przy użyciu fantomu wodnego wraz z komorą jonizacyjną, a mierzone profile są poddawane analizie zgodnie $\mathrm{z}$ raportem IAEA TRS-398. [4,5,6]

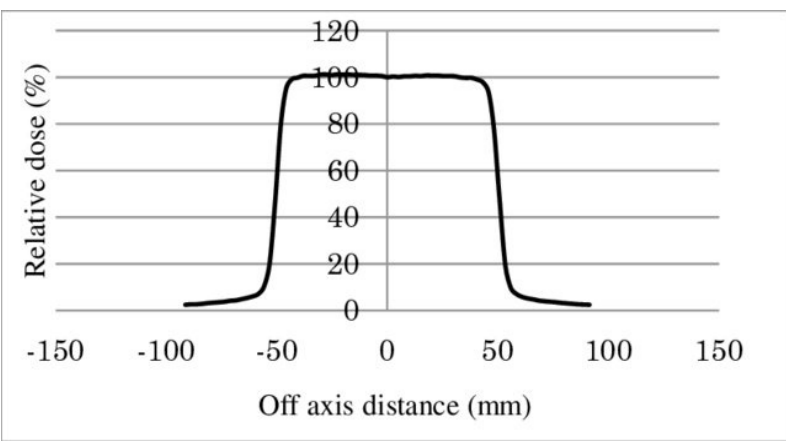

Rys. 1. Profil wiązki fotonowej 6MV dla pola $10 \mathrm{~cm} \times 10 \mathrm{~cm}$ na głębokości 1,5cm i SSD $100 \mathrm{~cm} .{ }^{1}$

Przez profil wiązki promieniowania rozumie się względny rozkład mocy dawki zmierzony w fantomie wodnym, w poprzek wiązki promieniowania, w stosunku do wartości mocy dawki w osi wiązki (Rys. 1.). Stałość profili (F) jest oceniana przez znalezienie na profilu wewnątrz 80\% szerokości wiązki wartości maksymalnej $\left(\mathrm{D}_{\max }\right)$ oraz minimalnej $\left(\mathrm{D}_{\min }\right)$ dawki i jest definiowana jako:

$$
F=100 \times \frac{D_{\max }-D_{\min }}{D_{\max }+D_{\min }}
$$

Symetria wiązki (S) oznacza stopień podobieństwa profilu między jedną stroną osi centralnej, a drugą. Typowym wymogiem jest, aby dwa dowolne punkty na profilu nie różniły się od siebie o więcej niż 2\%. Definiowana jest jako:

$$
S=100 \times \frac{\text { area }_{L}-\text { area }_{R}}{\text { area }_{L}+\text { area }_{R}}
$$

Do codziennej kontroli funkcjonowania akceleratorów medycznych przeznaczone jest urządzenie

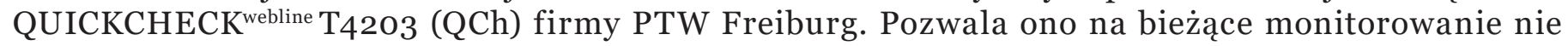
tylko wydajności akceleratora [7], ale także parametrów takich jak symetria wiązki promieniowania, standardowo kontrolowanych kwartalnie. Prawidłowe zastosowanie urządzenia QCh daje więc możliwość szybszej interwencji w razie pogorszenia tych właściwości, które w przeciwnym razie pozostałoby niewykryte i wpływało negatywnie na jakość radioterapii. Urządzenie zbudowane jest z bloku detektorów, układu elektronicznego oraz wyświetlacza i służy do przeprowadzania 
testów kontroli jakości akceleratorów medycznych stosowanych w radioterapii. Przyrząd w sposób automatyczny mierzy dawkę w osi centralnej (CAX) oraz kształt i parametry jakości wiązki na podstawie dawek promieniowania zmierzonych komorami jonizacyjnymi rozmieszczonymi zgodnie z ryc. 3 [3]. Producent rekomenduje pozycjonowanie urządzenia za pomocą centratorów laserowych, czyli systemu wskaźników laserowych znajdujących się w bunkrze akceleratora które wspomagają odtworzenie pozycji terapeutycznej pacjenta. Linie prawidłowo wyregulowanych centratorów laserowych powinny przecinać się w punkcie odpowiadającym izocentrum aparatu terapeutycznego. Rozporządzenie Ministra Zdrowia określa zakresy tolerancji dla zgodności wskaźników laserowych z krzyżem symulacji świetlnej pola promieniowania, którego ramiona przecinają się w osi centralnej wiązki. Tolerancja ta mieści się w zakresie \pm 2 milimetry. Ułożenie przyrządu zgodnie ze wskazaniem centratorów laserowych, których położenie mieści się we wspomnianym limicie, choć nie pokrywa się z krzyżem świetlnym, może prowadzić do znacznych niepewności pomiarowych i nieprawidłowej interpretacji wyników przeprowadzonych testów.

\section{Cel pracy}

Celem pracy było zbadanie wpływu dokładności ułożenia urządzenia QUICKCHECKwebline względem środka pola promieniowania na pomiar parametrów wiązki podczas codziennych testów kontroli jakości aparatu terapeutycznego oraz określenie jaki wpływ na te parametry ma przesunięcie urządzenia o konkretne wartości w kierunkach wzdłużnym oraz poprzecznym.

\section{Materiały i metody}

Pomiary zostały wykonane na akceleratorze medycznym TrueBeam (TB) firmy Varian (Varian Medical System, Palo Alto, USA) urządzeniem QUICKCHECK ${ }^{\text {webline }}$ T4203. Podczas codziennej kontroli jakości aparatu przez trzydzieści jeden dni urządzenie było pozycjonowane zarówno za pomocą centratorów laserowych jak i za pomocą krzyża symulacji świetlnej. Zestawiono przebiegi zmienności w czasie wyznaczonych parametrów, a także wyznaczono współczynniki korelacji Pearsona dla poszczególnych wartości uzyskanych na podstawie pomiarów wykonanych urządzeniem wypozycjonowanym z zastosowaniem dwóch porównywanych metod:

1. Zgodnie ze wskazaniem krzyża symulacji świetlnej pola promieniowania

2. Zgodnie ze wskazaniem centratorów laserowych

Dodatkowo, dla oceny wpływu przemieszczenia przyrządu względem środka pola promieniowania, przeprowadzono pomiary urządzeniem ułożonym zgodnie z polem świetlnym, które przyjęto jako referencyjne, a następnie z wygenerowanym błędem ułożenia polegającym na przesunięciu o $3,5 \mathrm{i} 7 \mathrm{~mm}$ w kierunku poprzecznym (LAT) oraz wzdłużnym ( $L O N G)$.

\section{Urządzenie pomiarowe}

Na rysunku (rys. 3.) został przedstawiony widok urządzenia QCh od strony wejścia wiązki. Wyraźnie oddzielone zostały od siebie obszar elektroniki oraz obszar napromieniany, gdzie znajdują się detektory. Urządzenie zostało wyposażone w znaczniki ułatwiające jego pozycjonowanie zarówno zgodnie z wymiarami pola świetlnego jak i z centratorami laserowymi. Układ pomiarowy (rys. 3.) składa się z zestawu powietrznych komór jonizacyjnych. Dziewięć z nich (komory CAX, G, T, L i R) o objętości pomiarowej $0,1 \mathrm{~cm}^{3}$ odpowiada za pomiar dawki w osi centralnej, symetrii oraz stałości profili wiązki promieniowania. Cztery komory (komory E) o objętości pomiarowej 0,2 $\mathrm{cm}^{3}$ służą do pomiaru energii i odpowiadają pomiarowi w wodzie na głębokości 5,3cm (E1), 3,7cm (E2), 2,8cm (E3) i 1,5cm (E4), ich wskazania wykorzystywane są przez urządzenie do wyznaczenia parametru jakości wiązki (ang. Beam Quality Factor, BQF) [3]. 


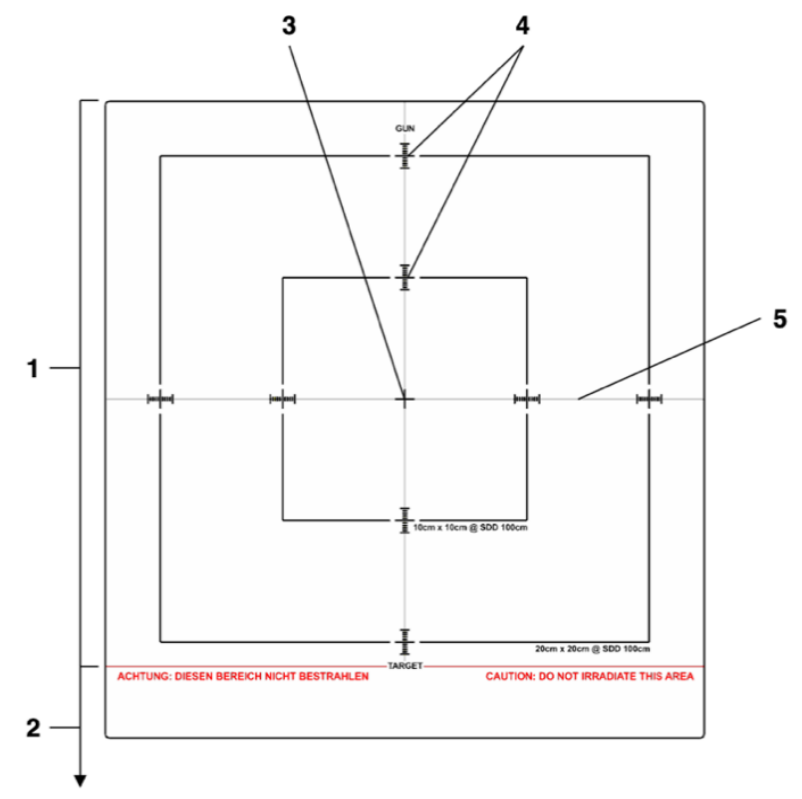

Rys. 2. QuickCheck widok urządzenia od strony wejścia wiązki [3]. Na rysunku widoczne są:

1. Obszar napromieniany z blokiem detektorów;

2. Obszar elektronik;

3. Położenie osi środkowej wiązki;

4. Znaczniki wielkości pola oraz pozycjonowania zgodnie z polem świetlnym;

5. Krzyż do pozycjonowania urządzenia zgodnie $\mathrm{z}$ centratorami laserowymi.

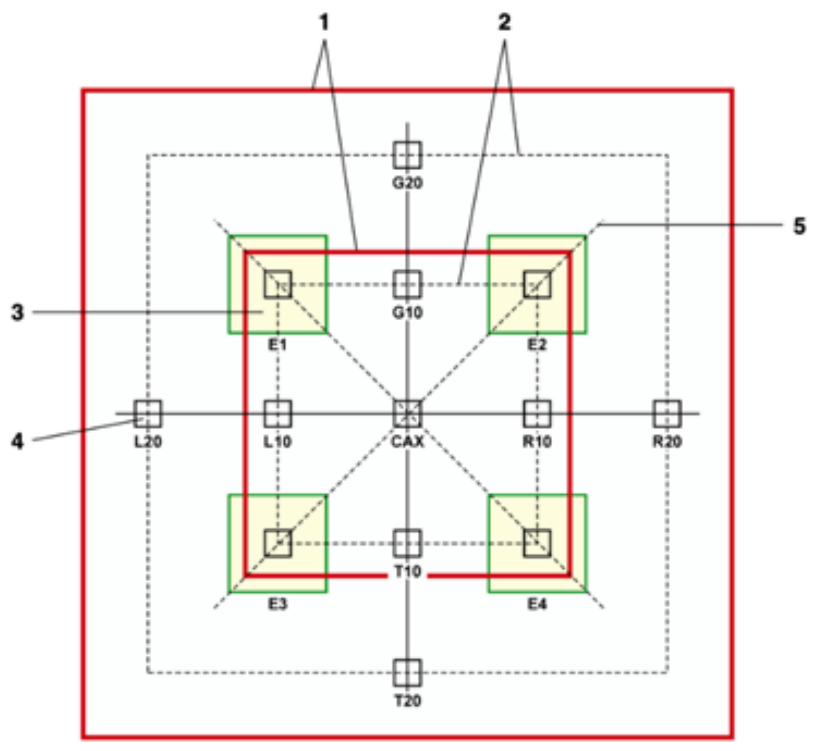

Rys. 3. Schemat rozmieszczenia komór jonizacyjnych [3]. Na rysunku widoczne są:

1. Obszar napromieniany;

2. 80\% obszaru napromienianego;

3. Komory do pomiaru energii;

4. Komory pomiarowe;

5. Przekątna pola pomiarowego;

\section{Mierzone parametry}

Parametr CAX odpowiada dawce promieniowana zmierzonej przez centralnie położoną komorę jonizacyjną (rys. 2) i służy do oceny stałości wydajności akceleratora. Dawka ta obliczana jest automatycznie przez urządzenie na podstawie wzoru [3]:

gdzie:

$$
C A X=M_{C A X} \cdot N_{C A X} \cdot k_{T P}
$$

- CAX - dawka zmierzona przez komorę CAX;

- $\mathrm{M}_{\mathrm{CAX}}$ - ladunek zmierzony przez komorę $\mathrm{CAX}$;

- $\mathrm{N}_{\mathrm{CAX}}$ - współczynnik kalibracyjny 6oCo komory CAX;

- $\mathrm{k}_{\mathrm{TP}}$ - współczynnik korekcji gęstości powietrza.

Korekcja gęstości powietrza obliczana jest zgodnie z wzorem:

$$
k_{T P}=\frac{(273,2+T) \cdot P_{0}}{\left(273,2+T_{0}\right) \cdot P}
$$

gdzie:

- T - temperatura $\mathrm{w}^{\circ} \mathrm{C}$ mierzona przez urządzenie;

- P - ciśnienie atmosferyczne w hPa mierzone przez urządzenie;

- $\mathrm{T}_{\mathrm{o}}$ - temperatura normalna: $2 \mathrm{O}^{\circ} \mathrm{C}$;

- $\mathrm{P}_{\mathrm{o}}$ - ciśnienie normalne: 1013,25hPa. 
Symetria w urządzeniu QUICKCHECK ${ }^{\text {webline }}$ T42031 jest mierzona osobno w kierunku GT (gun-target) oraz LR (left-right). Dla pola o wymiarach 10cm x 10cm wykorzystywane są komory T10 i G10 lub L10 i R10, a dla pola o wymiarach $20 \mathrm{~cm} \times$ 20cm: T10, T20, G10 i G20 lub L10, L20, R10 i R20 [3].

Symetria znormalizowana do $100 \%$ jest obliczana na postawie algorytmu [3]:

$$
\begin{gathered}
S_{L R}=100 \cdot\left(k_{\text {norm }}\right)_{S y m L R} \cdot \underset{x=L 10}{\operatorname{MAX}}\left[\frac{\operatorname{Max}\left(D_{-x} D_{x}\right)}{\operatorname{Min}\left(D_{-x} D_{x}\right.} .\right. \\
S_{G T}=100 \cdot\left(k_{\text {norm }}\right)_{\text {SymGT }} \cdot \underset{x=G 10}{\operatorname{MAX}}\left[\frac{\operatorname{Max}\left(D_{-x} D_{x}\right)}{\operatorname{Min}\left(D_{-x} D_{x}\right.} .\right.
\end{gathered}
$$

gdzie:

- $\left(\mathrm{k}_{\text {norm }}\right)_{\text {SymLR }}$ - współczynnik normalizacji w kierunku LR;

- $\left(\mathrm{k}_{\text {norm }}\right)_{\text {SymGT }}$ - współczynnik normalizacji w kierunku GT;

- $\mathrm{D}_{\mathrm{x}}, \mathrm{D}_{-\mathrm{x}}$ - wartość dawki zmierzonej przez komorę jonizacyjną w pozycji x i -x,

gdzie pozycje te są symetryczne względem środka wiązki.

Indeks jakości promieniowania (BQF) można za pomocą urządzenia QUICKCHECKwebline T42031 określić dla otwartych pól o wymiarach $10 \mathrm{~cm}$ x $10 \mathrm{~cm}$ dla wiązki fotonowej i $20 \mathrm{~cm}$ x $20 \mathrm{~cm}$ dla elektronów. Wykorzystywane są do tego komory CAX oraz jedna z komór jonizacyjnych E1, E2, E3 lub E4 (rys. 2). Indeks ten jest wyznaczany na podstawie wzoru [3]:

gdzie:

$$
B Q F=\left(k_{n o r m}\right)_{B Q F} \cdot \sum \frac{D_{E i}}{C A X}
$$

- $\left(\mathrm{k}_{\mathrm{norm}}\right)_{\mathrm{BQF}}-$ współczynnik normalizacji indeksu jakości promieniowania;

- $\mathrm{D}_{\mathrm{Ei}}$ - wartość dawki zmierzonej przez komorę jonizacyjną w pozycji E;

- CAX - wartość dawki zmierzonej przez komorę CAX.

\section{Wyniki}

Nie zaobserwowano wpływu zmiany sposobu pozycjonowania urządzenia pomiarowego na mierzone wartościCAX. Przebiegizmienności w31-dniowym okresieobserwacji parametru wyznaczonego urządzeniem pozycjonowanym na dwa porównywane sposoby są ze sobą zbieżne (ryc. 4, 5). Współczynniki korelacji Pearsona obliczone dla wartości CAX wyznaczonych dla dwóch porównywanych metod pozycjonowania przyrządu pomiarowego wynoszą $\mathrm{R}=0,97$ dla wiązki o energii $6 \mathrm{MV}$ oraz $\mathrm{R}=0,95$ dla energii $15 \mathrm{MV}$, co w obu przypadkach wskazuje na bardzo silną korelację.

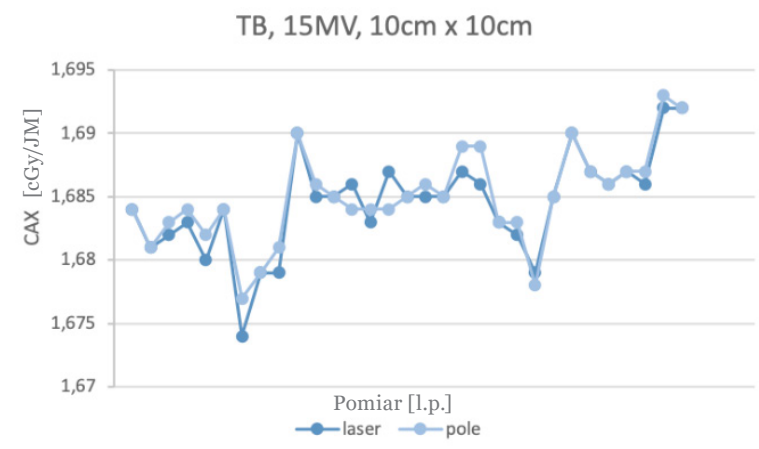

Rys. 4. Zmienność wartości CAX w czasie dla aparatu TrueBeam (TB) i wiązki 6MV.

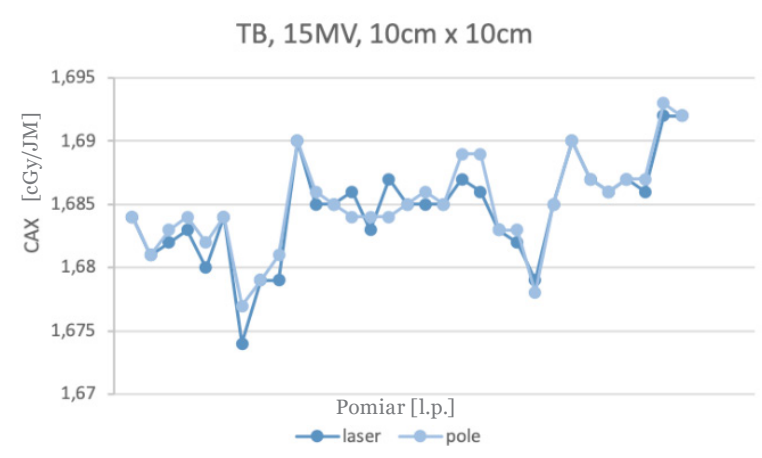

Rys. 5. Zmienność wartości CAX w czasie dla aparatu TrueBeam (TB) i wiązki 15MV. 


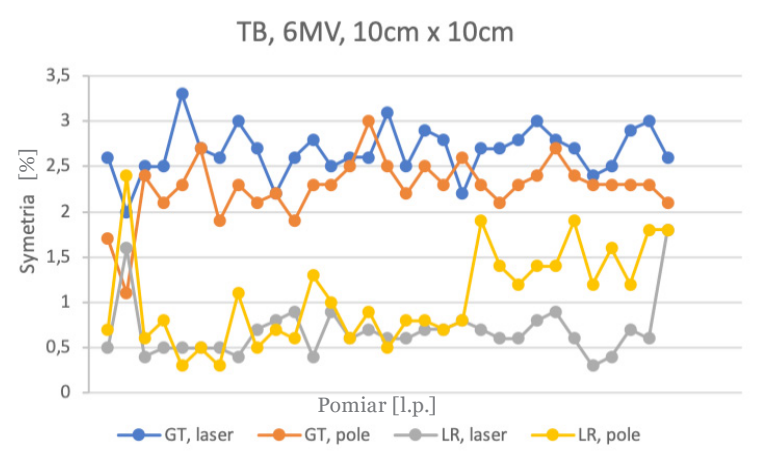

Rys. 6. Zmienność wartości symetrii w czasie dla aparatu TrueBeam (TB) i wiązki 6MV.
$\mathrm{TB}, 15 \mathrm{MV}, 10 \mathrm{~cm} \times 10 \mathrm{~cm}$

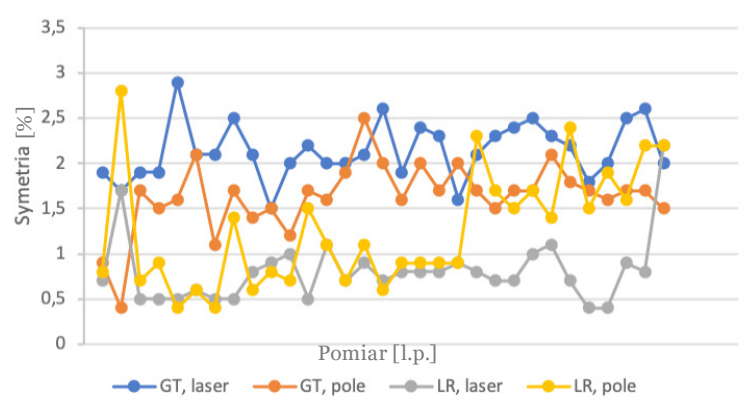

Rys. 7. Zmienność wartości symetrii w czasie dla aparatu TrueBeam (TB) i wiązki 15MV.

Jednocześnie odnotowano, że w przypadku symetrii wiązki promieniowania wyznaczonej na postawie pomiarów wykonanych urządzeniem wypozycjonowanym dwiema porównywanymi metodami wzajemna zgodność wyników jest znacząco niższa. Na rys. 6 została przedstawiona zmienność wartości symetrii dla 31-dniowego okresu obserwacji zmierzona dla aparatu TrueBeam (TB), wiązki $6 \mathrm{MV}$ i pola $10 \mathrm{~cm}$ x $10 \mathrm{~cm}$, a na rys. 7 dla wiązki fotonowej o energii $15 \mathrm{MV}$. Współczynniki korelacji Pearsona dla symetrii GT wynoszą o,27 dla energii $6 \mathrm{MV}$ i o,29 dla $15 \mathrm{MV}$, a dla symetrii LR odpowiednio: 0,27 i 0,37 .

Zestawienie odchyleń od wartości referencyjnej symetrii GT i RL wyznaczonych urządzeniem wypozycjonowanym dwiema porównywanymi metodami dla ww. wiązek zostało przedstawione w tabeli 1.

Tabela 1. Wartości średnie symetrii zmierzonej za pomocą urządzenia QCh dla aparatu TrueBeam dla 31-dniowego okresu obserwacji.

\begin{tabular}{|c|c|c|c|c|}
\cline { 2 - 5 } \multicolumn{1}{c|}{} & \multicolumn{2}{c|}{$6 \mathrm{MV}$} & \multicolumn{2}{c|}{$15 \mathrm{MV}$} \\
\cline { 2 - 5 } \multicolumn{1}{c|}{} & laser & pole świetlne & Laser & pole świetlne \\
\hline Symetria G-T & $2,671 \pm 0,268$ & $2,271 \pm 0,327$ & $2,142 \pm 0,309$ & $1,639 \pm 0,376$ \\
\hline Symetria L-R & $0,687 \pm 0,309$ & $1,055 \pm 0,523$ & $0,810 \pm 0,360$ & $1,261 \pm 0,635$ \\
\hline
\end{tabular}

TB, $6 \mathrm{MV}, 10 \mathrm{~cm} \times 10 \mathrm{~cm}$

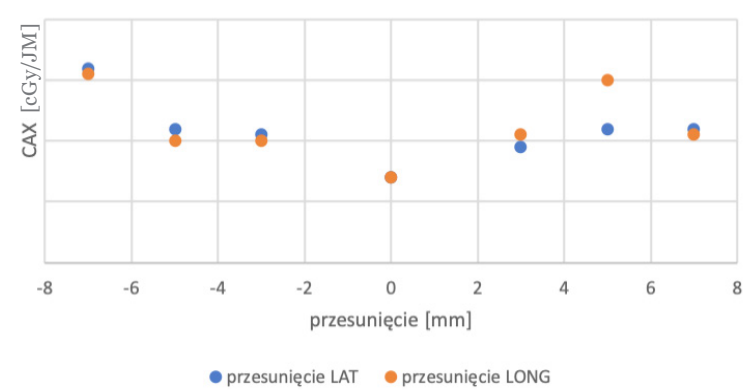

Rys. 8. Wykres zależności wartości CAX od wartości przesunięcia urządzenia pomiarowego w kierunku poprzecznych (LAT) oraz wzdłużnym (LONG).
$\mathrm{TB}, 6 \mathrm{MV}, 10 \mathrm{~cm} \times 10 \mathrm{~cm}$

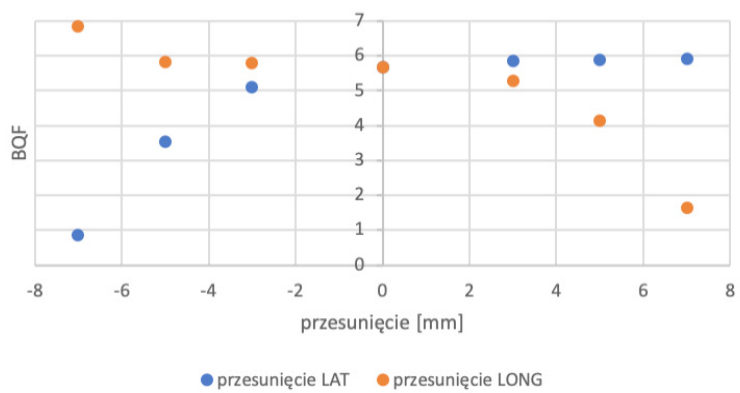

Rys. 9. Wykres zależności wartości BQF od wartości przesunięcia urządzenia pomiarowego w kierunku poprzecznych (LAT) oraz wzdłużnym (LONG). 
Maksymalna różnica pomiędzy wynikiem pomiaru CAX w izocentrum, a wskazaniem przesuniętego urządzenia o 3, 5, 7mm w kierunku zarówno wzdłużnym jak i poprzecznym nie przekracza 2\% (rys. 8.) Wartość zmierzonego parametru BQF spada wraz ze wzrostem przesunięcia urządzenia pomiarowego (rys. 9). Maksymalna różnica, wynikająca z przesunięcia QCh o $7 \mathrm{~mm}$ wynosi niemal 70\% względem wartości referencyjnej wyznaczonej dla urządzenia ustawionego w osi wiązki.

Na wartość symetrii w kierunku G-T miała wyraźny wpływ zmiana położenia urządzenia w kierunku LONG (rys. 10), natomiast w przypadku symetrii L-R widoczna zmiana w jej wartości zaszła, gdy urządzenie zostało przesunięte $\mathrm{w}$ kierunku LAT (rys. 11). Przesunięcie urządzenia o $3 \mathrm{~mm} \mathrm{w}$ dowolnym kierunku powodowało zmianę wartości odpowiadającej mu symetrii - GT lub LR - o 6\%, przesunięcie o 5mm o 13\%, a $7 \mathrm{~mm}$ przesunięcie powodowało zmianę wartości parametru o 32\%.

$\mathrm{TB}, 6 \mathrm{MV}, 10 \mathrm{~cm} \times 10 \mathrm{~cm}$

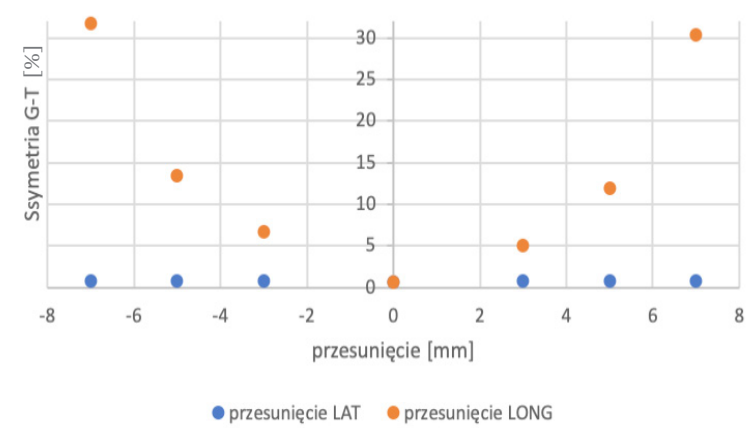

Rys. 10. Wykres zależności wartości symetrii G-T od wartości przesunięcia urządzenia pomiarowego w kierunku poprzecznych (LAT) oraz wzdłużnym (LONG).
$\mathrm{TB}, 6 \mathrm{MV}, 10 \mathrm{~cm} \times 10 \mathrm{~cm}$

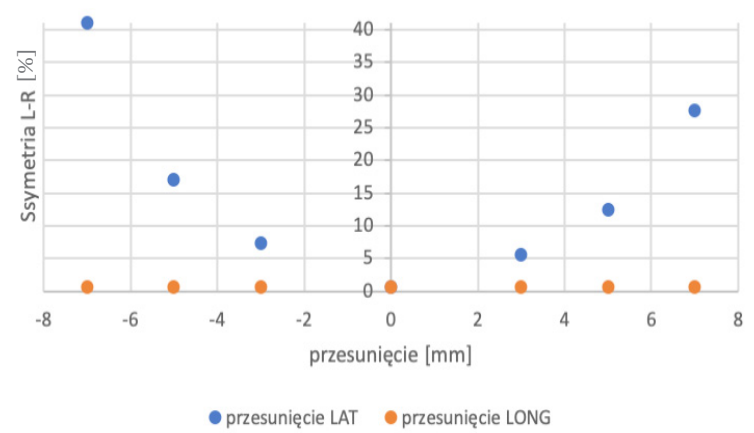

Rys. 11. Wykres zależności wartości symetrii L-R od wartości przesunięcia urządzenia pomiarowego w kierunku poprzecznych (LAT) oraz wzdłużnym (LONG).

\section{Dyskusja}

W 31-dniowym okresie obserwacji położenie centratorów laserowych względem krzyża symulacji świetlnej pola promieniowania zawierało się w zdefiniowanym przez rozporządzenie Ministra Zdrowia limicie tolerancji. Wypozycjonowanie urządzenia QCh zgodnie z wskazaniami laserów powodowało jednak widoczne przesunięcie przyrządu względem pola świetlnego (Rys. 12).

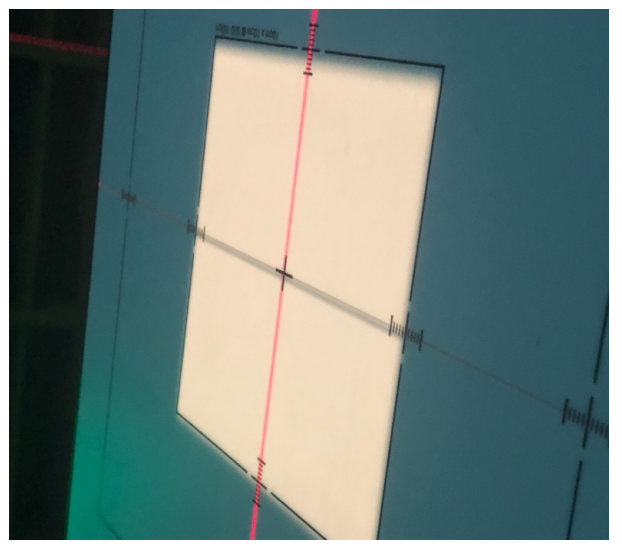

Rys. 12. Urządzenie wypozycjonowane względem centratorów laserowych z widocznym przesunięciem względem symulacji pola promieniowania.
Codzienne dopuszczenie akceleratora do użytku klinicznego oparte jest o pomiar dawki w osi centralnej wiązki. Zaobserwowane przesunięcie było zbyt małe by w sposób istotny wpłynąć na wartość tego parametru - niezależnie od wprowadzenia korekty położenia urządzenia względem pola świetlnego lub jej braku uzyskane wyniki pomiaru były zbliżone. Chcąc korzystać jednak z dodatkowych możliwości jakie daje urządzenie QUICHCHECK ${ }^{\text {webline, }}$ takich jak bieżąca ocena symetrii i jakości wiązki promieniowania, należy wziąc pod uwagę, że ze względu na sposób wyznaczenia tych parametrów przez QCh, zmierzone wartości zależą od dokładności ułożenia urządzenia względem pola świetlnego i nawet nieduże przesunięcia urządzenia wynikające $\mathrm{z}$ nieznacznego odchylenia położenia centratorów laserowych względem krzyża świetlnego mają odzwierciedlenie w rozbieżności wyników pomiarów.

Powyższe obserwacje znalazły potwierdzenie $\mathrm{w}$ teście celowo wygenerowanych błędów pozycjonowania urządzenia. Wrażliwość 
parametru CAX wyznaczanego na podstawie pomiaru pojedynczą centralną komorą jonizacyjną na przesunięcie urządzenia QCh jest wyraźnie niższa niż wrażliwość parametrów opisujących kształt profilu i jakość wiązki, które obliczane są przez przyrząd na podstawie pomiarów wykonanych różnymi układami komór.

\section{Podsumowanie}

Urządzenie QUICKCHECK ${ }^{\text {webline }}$ T4203 firmy PTW Freiburg może być szyblkim oraz łatwym w obsłudze narzędziem, które stanowi doskonałe źródło istotnych informacji o parametrach wiązki terapeutycznej oraz pracy aparatu w codziennej praktyce klinicznej ośrodka radioterapii. Należy jednak dołożyć wszelkich starań, by było ono dokładnie wypozycjonowane, a centratory laserowe odpowiednio wyregulowane. Nawet niewielkie przesunięcie aparatury może mieć wpływ na niepewności pomiarowe - w głównej mierze na wartość symetrii wiązki terapeutycznej. Zmiana położenia o $3 \mathrm{~mm}$ w dowolnym kierunku lateralnym lub wzdłużnym prowadzi już do zmiany wartości symetrii o 6\%, 13\% przy przesunięciu o $5 \mathrm{~mm}$ i $32 \%$ przy przesunięciu o $7 \mathrm{~mm}$.

Dla zapewnienia dokładności pomiarów i aby urządzenie mogło być z powodzeniem wykorzystywane podczas codziennych testów kontroli jakości należy przeprowadzić weryfikację ułożenia urządzenia względem symulacji pola świetlnego, a także przyjąć mniejszy zakres tolerancji dla rozbieżności centratorów laserowych względem krzyża symulacji świetlnej pola promieniowania, niż ten wynikający z Rozporządzenia Ministra Zdrowia [4].

\section{Bibliografia}

[1] Malicki, J, Ślosarek, K., red., Planowanie leczenia i dozymetria w radioterapii, Via Medica, Gdańsk 2016.

[2] Kukułowicz, P., Charakterystyka wiązek terapeutycznych stosowanych w radioterapii, Komitet Fizyki Medycznej, Radiobiologii i Diagnostyki Obrazowej PAN, Polskie Towarzystwo Fizyki Medycznej, Wrocław 2017.

[3] User Manual QUICKCHECK System QUICKCHECKwebline T4203. PTW.

[4] Obwieszczenie Ministra Zdrowia z dn. 3 kwietnia 2017r. w sprawie ogłoszenia jednolitego tekstu rozporządzenia Ministra Zdrowia w sprawie warunków bezpiecznego stosowania promieniowania jonizującego dla wszystkich rodzajów ekspozycji medycznej. Dz. U. 2017 poz. 884.

[5] IAEA. Technical Report Series no. 398, Absorbed Dose Determination in External Beam Radiotherapy: An International Code of Pracice for Dosimetry Based on Standards of Absorbed Dose to Water. Vienna, 2000.

[6] Łobodziec, W., Dozymetria promieniowania jonizującego w radioterapii, Wydawnictwo Uniwersytetu Śląskiego, Katowice 1999.

[7] Borowska, P., Sobocka-Kurdyk, U., \& Pawałowski, B., Wdrożenie urządzenia QuickCheck firmy PTW do codziennej kontroli stabilności wydajności akceleratorów medycznych. Letters in Oncology Science, 15(4), 150-156, 2019.

\section{Przypisy}

[1] Żródło obrazu: https://www.researchgate.net/profile/Mohamed-Bencheikh/publication/322807727/figure/fig2/ AS:588613804912640@1517347875666/Dose-profiles-of-6-MV-photon-beam-produced-by-Varian-Clinac-2100linear-accelerator-as_W640.jpg 